\title{
Az Orvosi Hetilap idézetelemzése mutatószámok alapján 2012 és 2016 között
}

\author{
Berhidi Anna - Szluka Péter - Vasas Lívia dr. \\ Semmelweis Egyetem Központi Könyvtár, Budapest
}

\begin{abstract}
Bevezetés: Egy tudományos folyóirat esetében tartani kell a tudományos színvonalat a tudományos adatbázisokba - Web of Science, Journal Citation Reports - kerülés után is.

Célkitüzés: A dolgozat célja az Orvos Hetilap idézetelemzése 2012 és 2016 között különféle mutatószámok alapján, elsősorban a szerzők által korábban írt, 2012-ben megjelent Orvosi Hetilap-cikk adatainak összevetésével.

Módszer: A szerzők 2013-2015-ben megjelent Orvosi Hetilap-füzetszámokat vizsgáltak, és különböző adatbázisokban kerestek le adatokat. Kiszámolták az Orvosi Hetilap 2012-2016-os impaktfaktorait, elemezték a 2015-2016. évi hivatalos impaktfaktorok bibliometriai összetevőit idéző folyóiratok, hivatkozások száma szerint; lekeresték az Orvosi Hetilap 2012-2016-os cikkeinek idézettségét; vizsgálták az Orvosi Hetilap tudományos teljesítményét egyéb mutatószámok alapján.

Eredmények: Az Orvosi Hetilap 2016-os hivatalos impaktfaktora, 0,349 az eddigi legmagasabb érték a korábbiakhoz viszonyítva. A folyóirat cikkeit továbbra is idézik külföldi szerző́k és magas impaktfaktorú lapok. A hivatkozott közlemények több mint 50\%-a open access elérésú. A leggyakrabban idézett cikk-kategóriák: eredeti és összefoglaló közlemények, esetismertetések. Az Orvosi Hetilap tudományos teljesítménye a SCImago weboldal és a Scopus adatbázis mutatószámai alapján biztató értékeket mutat a vizsgált évekre vonatkozóan. A folyóirat önidézettségi arányának átlaga 30\% körül mozog. Az Orvosi Hetilap h-indexe a Web of Science Core Collection adatbázisban 7, a Scopus adattárban 19.

Következtetések: A jelen cikk idézetelemzése megmutatja, hogy rövid távon is emelkedhetnek a hivatkozások és a különféle hányadosok értékei, de radikális változás hosszú távon történhet az eddig elért eredmények megtartásával és emelésével, szem előtt tartva a folyóirat előremutató fejlesztéseit.
\end{abstract}

Orv Hetil. 2018; 159(30): 1226-1234.

Kulcsszavak: indexelés, periodikák, bibliometria, impaktfaktor

\section{Citation analysis of the Hungarian-language Orvosi Hetilap based on indicators between 2012 and 2016}

Introduction: After getting indexed by scientific databases - Web of Science, Journal Citation Reports - the obtained scientific performance of the journal needs to be kept up.

Aim: The aim of this article is to analyse citation numbers based on different bibliometric indicators between 2012 and 2016 comparing data with an article published in 2012.

Method: Authors evaluated issues of Orvosi Hetilap published in 2013-2015 and searched data in various international databases. Number of citations, quality of citing journals were analysed based on the official 2015-2016 impact factor of Orvosi Hetilap. Scientific performance of the journal was evaluated according to data of SCImago webpage and Scopus database as well.

Results: The official 2016 impact factor of Orvosi Hetilap is 0,349 which is the highest value compared with the previous factors. The articles of Orvosi Hetilap are cited by international authors and high impact factor journals, too. Further, more than half of the publications cited are open access. The most frequently cited categories are original and review articles, and case reports. Scientific performance of Orvosi Hetilap is promising according to indicators of SCImago webpage and Scopus database. Mean self-citation rate of the journal is about $30 \%$. Its h-index is 7 in Web of Science Core Collection, and 19 in Scopus database.

Conclusions: Citation analysis of this article shows that citation numbers and various bibliometric indicators can increase in a short period, but drastic changes can only happen in a long period with keeping and pushing the obtained values, and focusing on the further development of the journal. 
Keywords: abstracting and indexing as topic, periodicals as topic, bibliometrics, journal impact factor

Berhidi A, Szluka P, Vasas L. [Citation analysis of the Hungarian-language Orvosi Hetilap based on indicators between 2012 and 2016]. Orv Hetil. 2018; 159(30): 1226-1234.

(Beérkezett: 2018. február 26.; elfogadva: 2018. április 2.)

Semmelweis Ignác születésének 200. évfordulója évében a Szerkesztőség felkérésére készített tanulmány.

\section{Rövidítések}

$\mathrm{CC}=$ Core Collection; $\mathrm{CSCD}=$ Chinese Science Citation Database; IF = impaktfaktor; JCR = Journal Citation Reports; RSCI = Russian Science Citation Index SciELO = Scientific Electronic Library Online Citation Index; SJR = SCImago Journal Rank; SNIP = Source Normalized Impact per Paper; WoS $=$ Web of Science

2012-ben jelent meg az Orvosi Hetilap elemzéséről szóló közlemény, amely a Web of Science (WoS) adatbázisba kerülés feltételeit vizsgálta [1]. Azóta az Orvosi Hetilap nagy utat tett meg: 2013-ban bekerült a Clarivate Analytics WoS Core Collection (CC) Science Citation Index Expanded adattárba, valamint 2015-ben megszerezte első hivatalos impaktfaktorát (IF), amely természetesen visszakereshető a Clarivate Analytics Journal Citation Reports (JCR) adatbázisban. Az Orvosi Hetilap 160 éves történetében tehát az első mérföldkőhöz, vagyis tulajdonképpen a fentiek alapján két mérföldkőhöz már megérkezett, de hátradőlni nem lehet, ahogy mondani szokás, „a java csak most jön”: megtartani a tudományos színvonalat és a lehetőségekhez képest tovább emelni azt.

Azon túl, hogy nagy nemzetközi adatbázis jegyzi a lapot, és IF-os mutatószámmal is rendelkezik, vajon milyen változásokon esett át 2012 óta? Az akkori közlemény az idézetelemzésre nagy hangsúlyt fektetett, amely még inkább követésre érdemes jelenség az Orvosi Hetilap IF-os lappá válásával. Az idézetek számának változása akár negatív, akár pozitív irányban az IF emelkedéséhez, és ha igazán fennköltek szeretnénk lenni, az IF bukásához is vezethet. Figyelni kell a folyóirat „önidézet-” számának alakulását. Ha magas arányt ér el, felülvizsgálhatják, nem történt-e visszaélés [1, 2]. Figyelni kell, hogy az idézetek „gyarapodjanak”. Az idézetszám stagnálása vagy erős apadása a nemzetközi vérkeringés peremére sodorhat egy lapot, és kiszoríthatja a nemzetközi adatbázisokból is. Ez persze a legrosszabb forgatókönyv egy korábban tudományos hírnevet szerzett lap számára. Éppen ezért, hogy ez semmiképpen se fordulhasson elö egy ebben a tekintetben eleve hátrányból induló folyóirat esetében - hiszen nemzeti nyelven jelenik meg -, még inkább fontos az idézetelemzés áttekintése.

\section{Módszer}

A 2012-es cikk [1] adatai közül az alábbiakat kívántuk összehasonlítani, illetve kiegészíteni adatbázisok (WoS Core Collection, Scopus, WoS Chinese Science Citation
Database, WoS Russian Science Citation Index, WoS SciELO Citation Index, Journal Citation Reports) lekeresései alapján: IF (nem hivatalos - lekeresésének módszerét lásd a 2012-es cikkben [1], hivatalos); IF bibliometriai összetevői ${ }^{1}$ : mely közleménytípusokra hivatkoztak, a hivatkozott közlemények open access cikkek voltak-e, hogyan alakult a hivatkozások száma az idéző közlemények szerzőségének magyar/külföldi eloszlásában, mely kategóriájú közlemény „hozta” a legtöbb hivatkozást, milyen idézettségi gyakoriság jellemzi az Orvosi Hetilap-cikkeket, milyen IF-értékű lapokban történt a hivatkozás; az Orvosi Hetilap idézettsége idézetkereső adatbázisokban a 2012 és 2016 közötti időszakra vonatkozóan.

A 2012-es cikktől függetlenül további idézettségi mutatószámokat és idézetelemzéseket is vizsgáltunk. Ezek felhasználásával is érzékeltetni kívántuk az Orvosi Hetilap helyzetét a nemzetközi közegben: a SCImago Journal Rank (SJR-) értéke, nemzetközi együttmúködés, az átlagos idézettség és az összes önidézettség eloszlása a 2012 és 2016 közötti időszakban. Ehhez a SCImago Journal \& Country Rank weboldalt [3] hívtuk segítségül, amely térítésmentesen biztosítja többek között az előbb említett mutatószámokat, adatokat. Egyéb mutatószámok (például CiteScore, h-index) alapján az Orvosi Hetilap teljesítményének „mérése” a Scopus [4] és WoS CC [5] adatbázisokat alapul véve.

\section{Eredmények}

\section{Az Orvosi Hetilap impaktfaktora (nem hivatalos - hivatalos)}

Az 1. táblázat IF-értékei közül látható, hogy az eddigi legmagasabb mutatószámot a 2016-os érték érte el. Hangsúlyozzuk, hogy a 2015-ös [6] és a 2016-os [7] IF-ok már hivatalos, a JCR adatbázisban visszakereshető mérôszámok.

\section{A 2015. és a 2016. évi hivatalos impaktfaktor bibliometriai összetevői}

A 2013 és 2015 között megjelent közlemények 2015. és 2016. évi idézettségét vizsgáltuk meg. Egyértelmű volt a választás, hogy helyhiány okán a hivatalos IF-ok szám-

A bibliometriai összetevók elemzése során az IF nevezőjéből csak az idézett cikkeket vizsgáltuk, valamint a számlálóból kiolvasható adatokat, vagyis a hivatkozásokat értékeltük. 
1. táblázat |Az Orvosi Hetilap nem hivatalos (2012-2014) és hivatalos (2015-2016) impaktfaktorának számítása

A 2012-2014. évi nem hivatalos impaktfaktoroknál az idézetek számát a Web of Science (WoS), az eredeti közlemények számát a PubMed adatbázisban kerestük le korábbi években.

A 2015-2016. évi impaktfaktorok forrása: 2015 és 2016, Journal Citation Reports ${ }^{\circledR}$ (Clarivate Analytics, c2017)

\begin{tabular}{|c|c|c|}
\hline IF $2012^{*}$ & $\begin{array}{l}\text { 2012-ben érkezett idézetek száma } \\
\text { a 2010-es és 2011-es cikkekre / } \\
\text { 2010-ben és 2011-ben megjelent } \\
\text { eredeti közlemények száma }\end{array}$ & $\begin{array}{l}90+36 / 287+ \\
285=0,220\end{array}$ \\
\hline IF $2013^{*}$ & $\begin{array}{l}\text { 2013-ben érkezett idézetek száma } \\
\text { a 2011-es és 2012-es cikkekre / } \\
\text { 2011-ben és 2012-ben megjelent } \\
\text { eredeti közlemények száma }\end{array}$ & $\begin{array}{l}83+83 / 285+ \\
260=0,305\end{array}$ \\
\hline IF $2014^{* *}$ & $\begin{array}{l}\text { 2014-ben érkezett idézetek száma } \\
\text { a 2012-es és 2013-as cikkekre / } \\
\text { 2012-ben és 2013-ban megjelent } \\
\text { eredeti közlemények száma }\end{array}$ & $\begin{array}{l}91+42 / 228+ \\
228=0,292\end{array}$ \\
\hline IF 2015 & $\begin{array}{l}\text { 2015-ben érkezett idézetek száma } \\
\text { a 2013-as és 2014-es cikkekre / } \\
\text { 2013-ban és 2014-ben megjelent } \\
\text { eredeti közlemények száma }\end{array}$ & $\begin{array}{l}66+72 / 229+ \\
245=0,291\end{array}$ \\
\hline IF 2016 & $\begin{array}{l}\text { 2016-ban érkezett idézetek száma } \\
\text { a 2014-es és 2015-ös cikkekre / } \\
\text { 2014-ben és 2015-ben megjelent } \\
\text { eredeti közlemények száma }\end{array}$ & $\begin{array}{l}71+103 / 245+ \\
253=0,349\end{array}$ \\
\hline
\end{tabular}

*IF 2012, 2013: önidézeteket (Orvosi Hetilap-idézeteket) még nem tartalmaz.

**IF 2014: közleményszám a WoS alapján; az idézetszám önidézeteket (azaz Orvosi Hetilap-idézeteket) is tartalmaz, mert 2013-tól indexeli a WoS az Orvosi Hetilapot.

adatait elemezzük, mint hogy a 2012-es cikkből „hiányzókat" mutassuk be teljes körúen.

Ha a kettőnél többször idézett közleménytípusokat a 2015-ben érkezett idézetek szerint vesszük górcső alá, elmondhatjuk, hogy a 2013-ban megjelent cikkek közül öt darabot háromszor, míg egyet (eredeti) ötször idéztek; míg a 2014-ben megjelent publikációk közül két darabot (egy eredeti, egy összefoglaló) háromszor, hármat (egy eredeti, két ajánlás) négyszer idéztek.

A 2016-ban érkezett idézeteket elemezve a 2014-ben megjelent cikkek közül két darabot (egy esetismertetés, egy összefoglaló) idéztek négyszer; míg a 2015-ben megjelent közlemények közül öt darabot (összefoglalók) ötször, egyet (szintén összefoglaló) hétszer idéztek.

Az 1. ábra a vizsgált időszak összes idézett közleményét szemlélteti, kiemelve ebból az open access cikkeket.

A 2. és a 3. ábra a független idézeteket, azaz nem az Orvosi Hetilapban megjelent cikkek hivatkozásait mutatja külföldi és magyar ${ }^{2}$ szerzőségüket vizsgálva.

Kategóriák szerinti bontásban is érdemes megnézni az Orvosi Hetilap cikkeinek idézettségét (4. ábra).

\footnotetext{
2 Magyar szerzőségú hivatkozásnak vettük az egyértelmúen magyar vagy magyarnak tűnő szerzői nevek alatti hivatkozásokat.
}

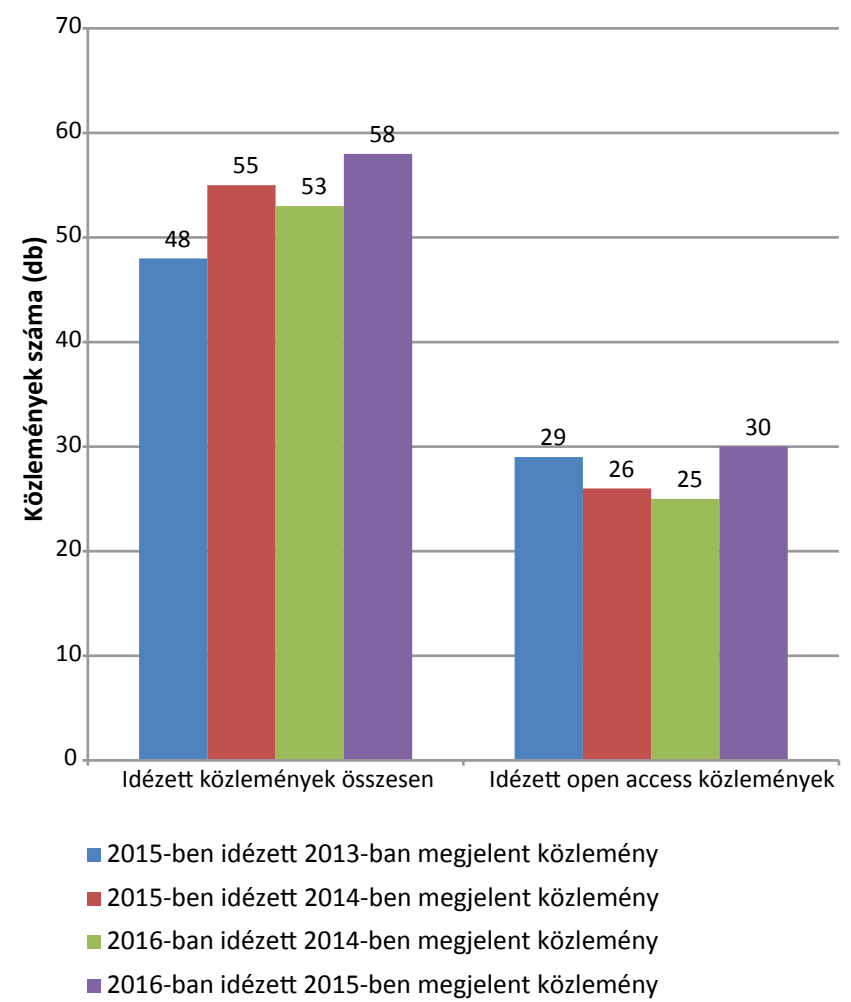

1. ábra 2015-ben és 2016-ban idézett, az adott évet megelőző két évben megjelent közlemények és ezek open access aránya

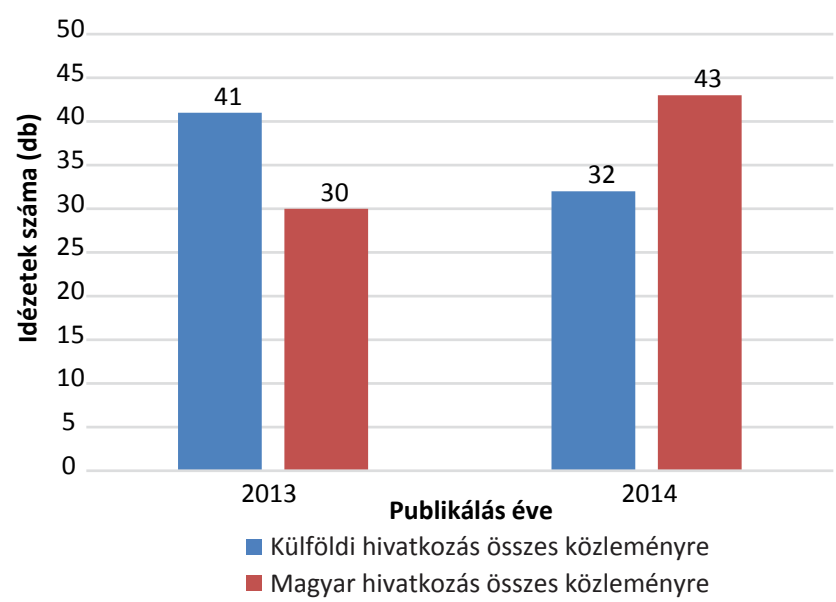

2. ábra $\mid$ 2015-ben történt független hivatkozások az Orvosi Hetilap megelőző két évben megjelent közleményeire

Független hivatkozáson a nem Orvosi Hetilapból érkező hivatkozásokat értjük

A korábbi évekhez hasonlóan (lásd 2012-es cikk [1]) az Orvosi Hetilap közleményeinek idézettségi gyakoriságát vizsgálva azt találtuk, hogy továbbra is nagy az egyszeres idézettségű közlemények túlsúlya, de eltolódtak az arányok az egyszeres idézettségü cikkeknél, valamint megjelentek a háromnál többször idézett cikkek is. 2010-2011-ben $82 \%$, illetve $81 \%$ az egyszeres idézettségű közlemények idézettségi gyakorisága, és háromnál 


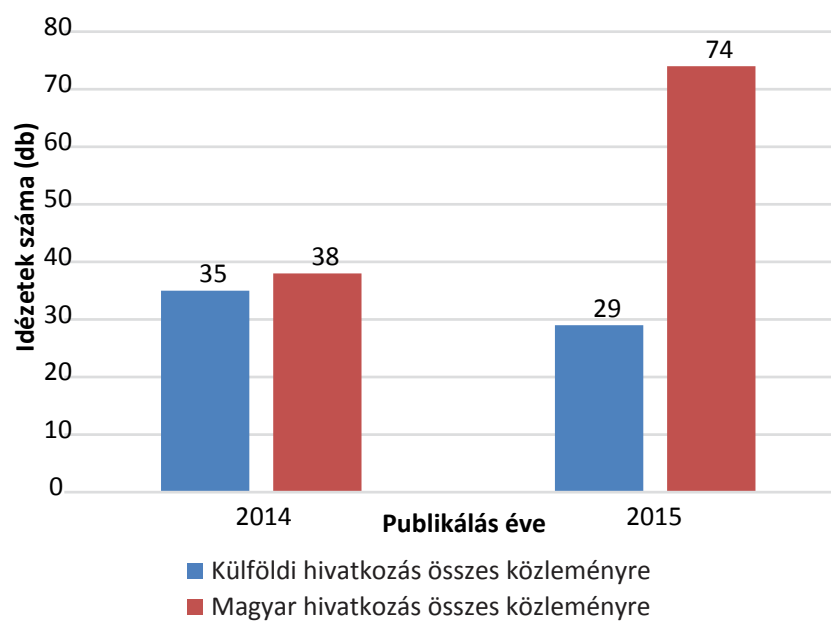

3. ábra

2016-ban történt független hivatkozások az Orvosi Hetilap megelőző két évben megjelent közleményeire

Független hivatkozáson a nem Orvosi Hetilapból érkező hivatkozásokat értjük

többször nem idéznek egy publikációt sem. A 2015. év IF-ának bibliometriai elemzésekor a hivatkozott cikkek idézettségi százalékos eloszlása az alábbiak szerint alakult: 74\% egyszeres idézettségú, 16\% kétszeres, 7\% háromszoros, 4\% háromnál többszörös; 2016-ban ez az arány csak kisebb eltérést mutat: 71\% egyszeres, 14\% kétszeres, $8 \%$ háromszoros, $7 \%$ háromnál többszörös.

Válogatást készítettünk azokból a tudományos lapokból, amelyek 2015-ben és 2016-ban az adott évet meg- előző két évben megjelent Orvosi Hetilap-közleményeket idézték: a három vagy annál magasabb IF-értékú idéző folyóiratokra fókuszáltunk. Eredeti, összefoglaló és esetismertetés kategóriájú cikkekre hivatkoztak ezek a magasabb IF-ral rendelkező lapok.

Két 8 körüli IF-értékkel bíró folyóiratot is találtunk: az Autoimmunity Reviews 2013-as eredeti közleményre hivatkozik 2015-ben, IF (2015) 8,490 [6], míg a Journal of Internal Medicine egy 2014-es esetismertetést idéz 2016-ban, IF (2016) 7,890 [7]. Kiugró adatként szerepel azonban a 2015-ben 37,684 IF-os [6] JAMA folyóiratból érkező hivatkozás: 2014-es esetismertetést idéz 2015-ben.

\section{Az Orvosi Hetilap idézettsége}

A 2. táblázat idézetkereső adatbázisokból kigyűjtött Orvosi Hetilap-hivatkozásokat szemléltet a vizsgált időszakban $[4,5,8-10]$.

\section{Az Orvosi Hetilap tudományos teljesitménye a SCImago Journal \& Country Rank weboldal alapján}

A térítésmentesen elérhető SCImago weboldalon az Orvosi Hetilap teljesítményét is áttekinthetjük [3]. A weboldal adatainak forrása a Scopus adatbázis, így ha az adattár indexel egy folyóiratot, annak teljesítménye kereshetôvé válik a weboldalon is. Helyhiány miatt nem

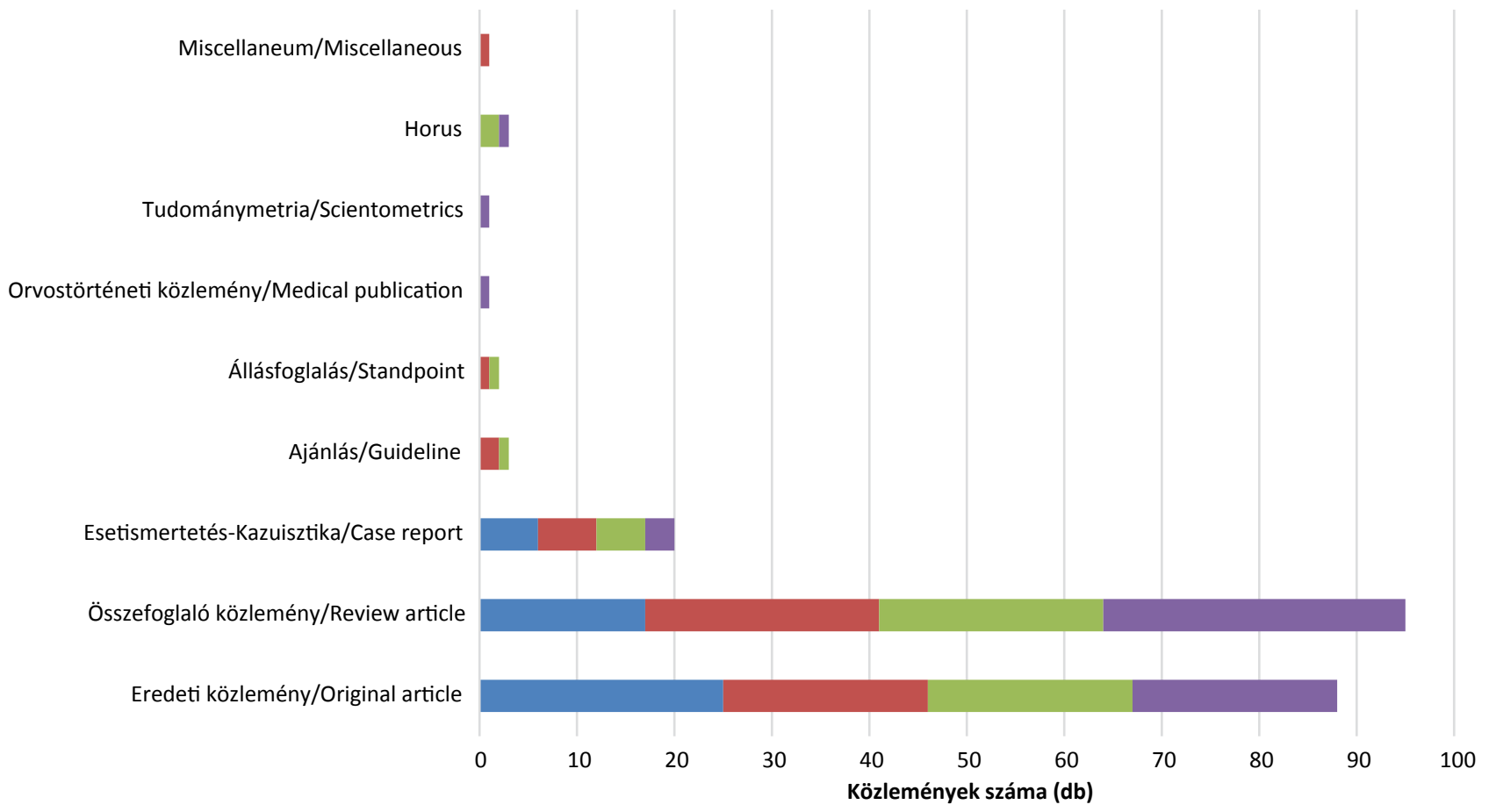

2015-ben idézett 2013-ban megjelent közlemény 2016-ban idézett 2014-ben megjelent közlemény

- 2015-ben idézett 2014-ben megjelent közlemény - 2016-ban idézett 2015-ben megjelent közlemény 
térünk ki az összes teljesítmény értékelésére. A SJR-mutatószám 2012 és 2016 között a 0,159-0,166 tartományban mozog.

Érdekes adatokat mutat az 5. ábra, amelyen százalékos eloszlásban tekinthetjük át az Orvosi Hetilapban megjelent közlemények nemzetközi együttmúködésének arányát.

A SCImago oldalon az átlagos idézettségi adatok is megtekinthetők [3], a vizsgált időszakra (2012-2016) vonatkozóan néztük meg ezt az eloszlást (6. ábra). Ki-

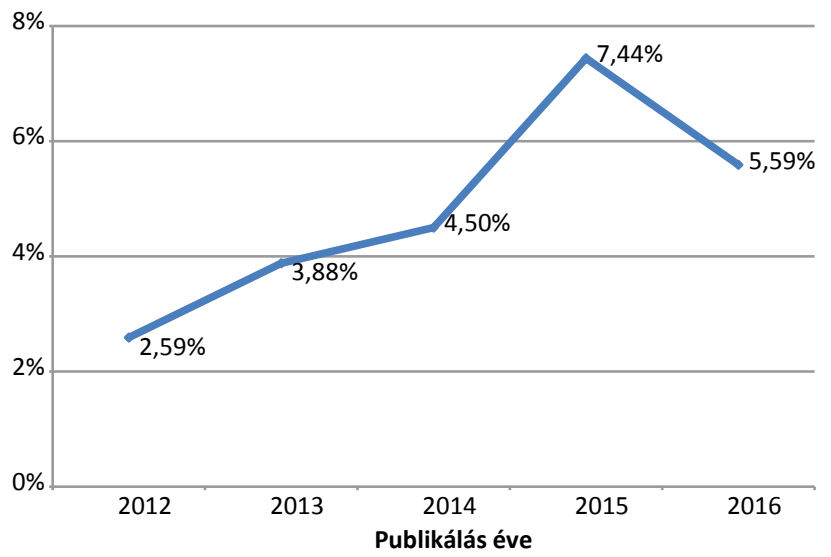

5. ábra $\mid$ A nemzetközi együttmúködés százalékos aránya az Orvosi $\mathrm{He}$ tilap 2012-2016-ban megjelent cikkeire vonatkozóan

Nemzetközi együttmúködésnek számít, ha több, mint egy or szág képviselteti magát a szerzők munkahelyi megjelölésénél.

Az értékeket a SCImago Journal \& Country Rank weboldalon kerestük le 2017 novemberében

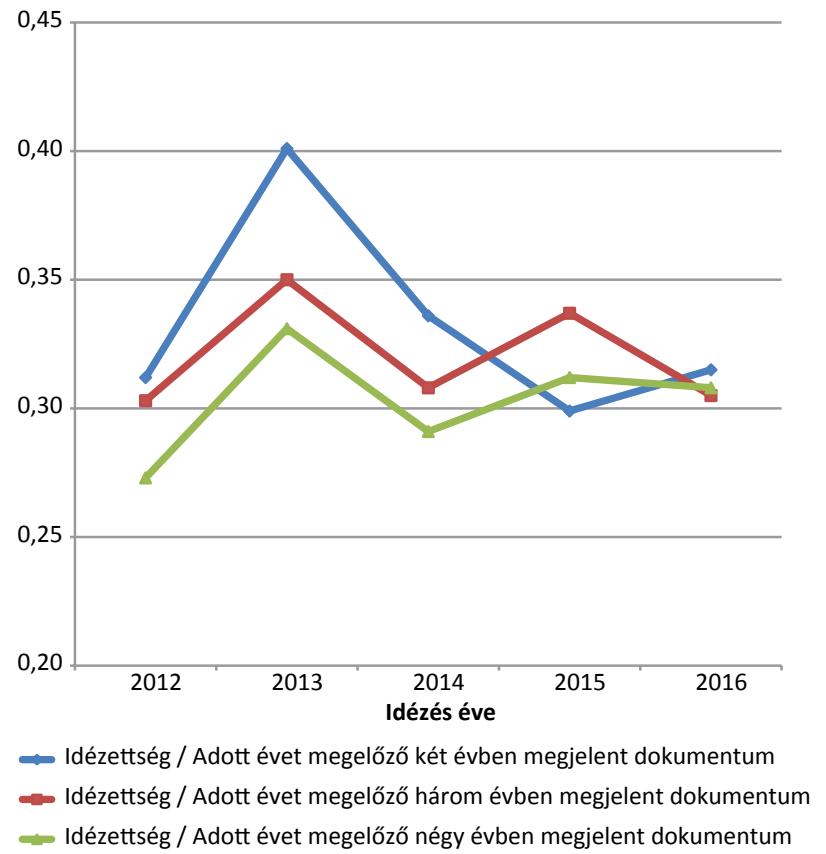

6. ábra

$$
\begin{aligned}
& \text { Az Orvosi Hetilap közleményeinek átlagos idézettsége } \\
& \text { Az értékeket a SCImago Journal \& Country Rank weboldalon } \\
& \text { kerestük le } 2017 \text { novemberében }
\end{aligned}
$$

emelnénk, hogy a 6. ábrán kékkel jelölt mérőszám megfelel az IF definíciójának, azonban ebben az esetben a Scopus adatbázisban szereplő idézetek alapján kerül kiszámításra az érték.

A 7. ábra szintén a SCImago oldal (közvetve a Scopus adatbázis) alapján jeleníti meg az Orvosi Hetilap közleményeinek összes és önidézettségére vonatkozó adatokat [3].

\section{Az Orvosi Hetilap tudományos teljesitménye egyéb mutatószámok (például CiteScore, b-index) alapján}

CiteScore-, SCImago Journal Rank, Source Normalized Impact per Paper értékek

Külön foglalkoztunk a Scopus adatbázis relatíve frissnek számító CiteScore-értékének vizsgálatával, illetve a Scopus adattár egyéb mutatószámokat, úgymint SJR (lásd fentebb), Source Normalized Impact per Paper (SNIP) is listáz az indexelt folyóiratoknál [11], ezért az említett mérőszámokat is megjelenítjük a 8 ábrán.

\section{$\mathrm{H}$-index}

2005 óta viszonylag töretlen népszerűséggel van jelen különböző adatbázisokban a Hirsch- vagy h-index-érték. Eredeti funkciója szerint a szerzók munkásságának teljesítményét hivatott bemutatni [12], de javasolták folyóiratokra is alkalmazni [13]. A jelen közlemény nem

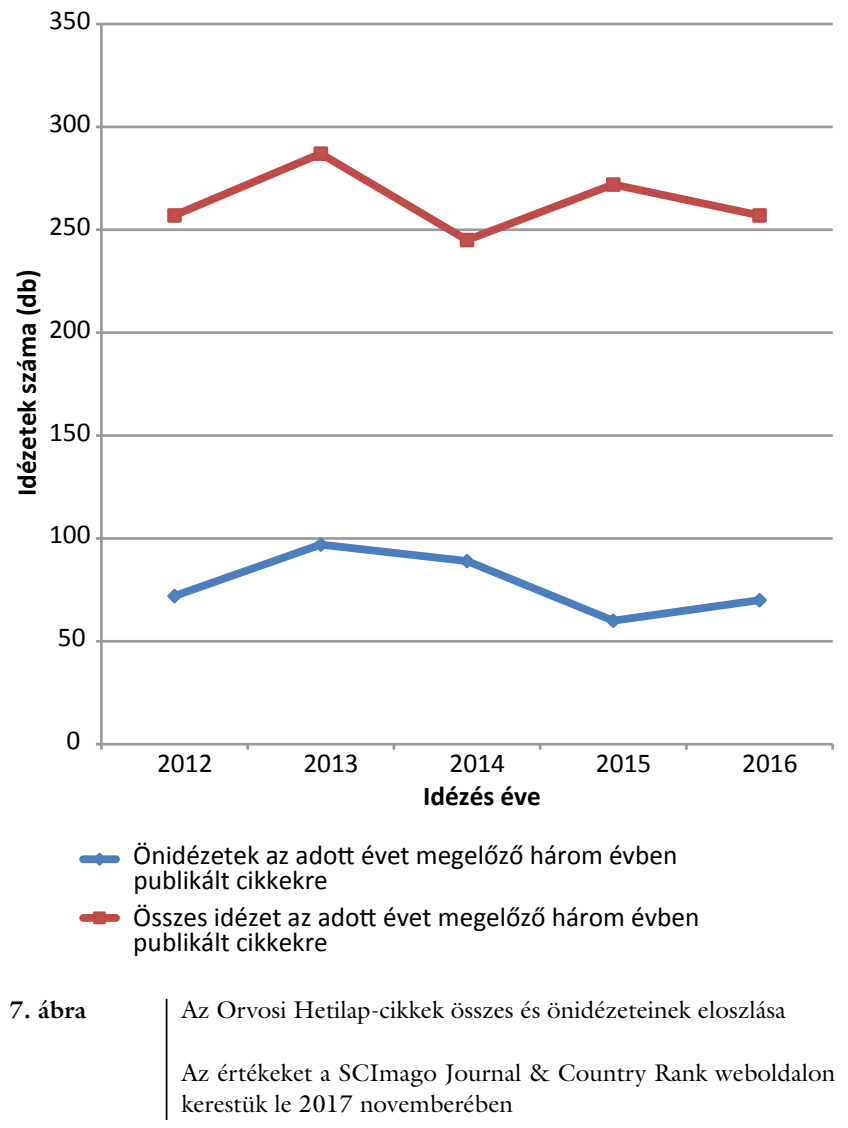




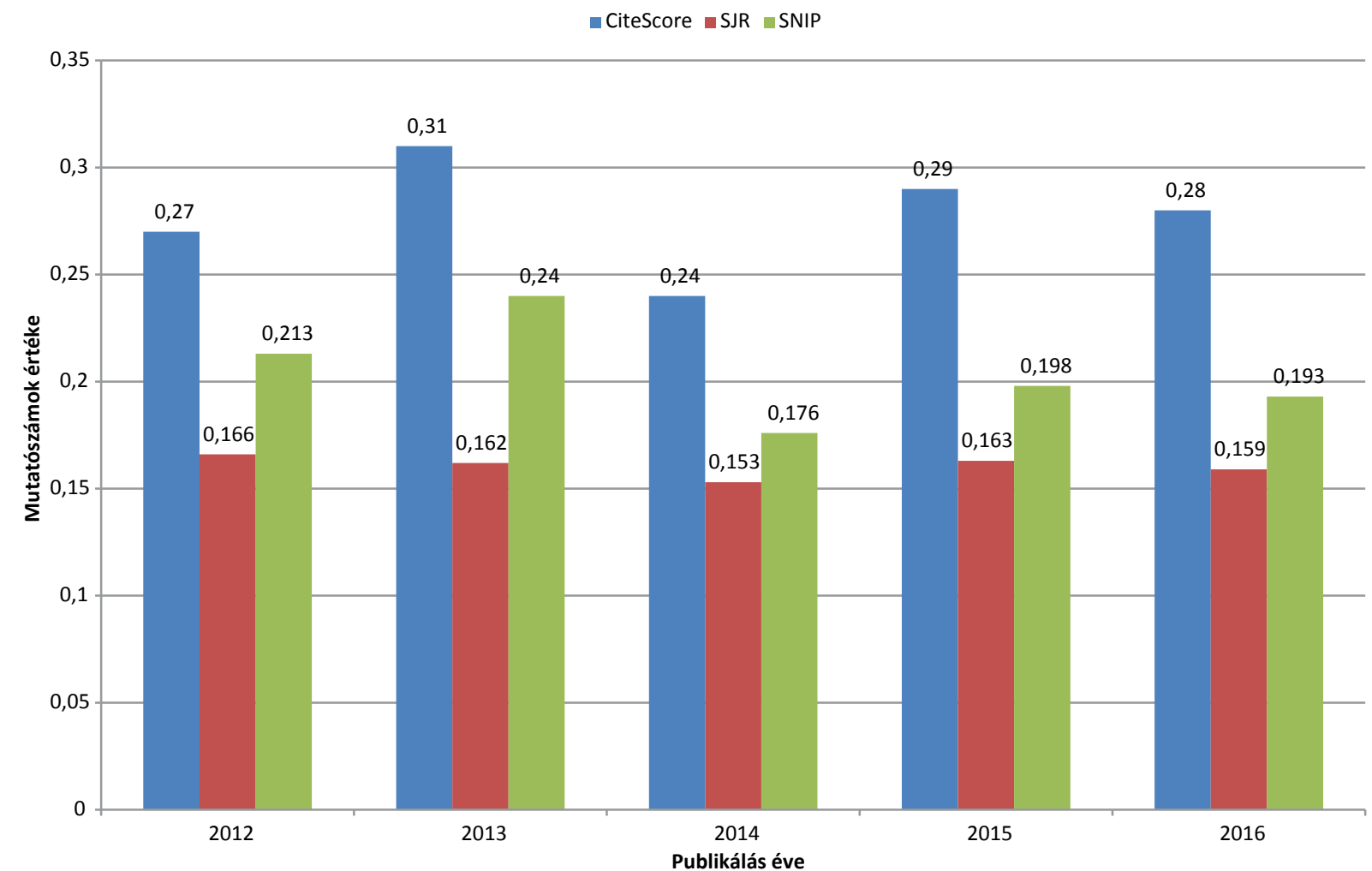

8. ábra

Az Orvosi Hetilap CiteScore-, SJR- és SNIP-értékei 2012 és 2016 között a Scopus adatbázis adatai alapján (a lekeresés ideje: 2017. december) A rövidítések feloldását lásd a jelen közlemény rövidítésjegyzékében. A forrás az irodalomjegyzékben van részletezve: a CiteScore [14, 15, 16, 17, 18], illetve a SNIP [19] esetében

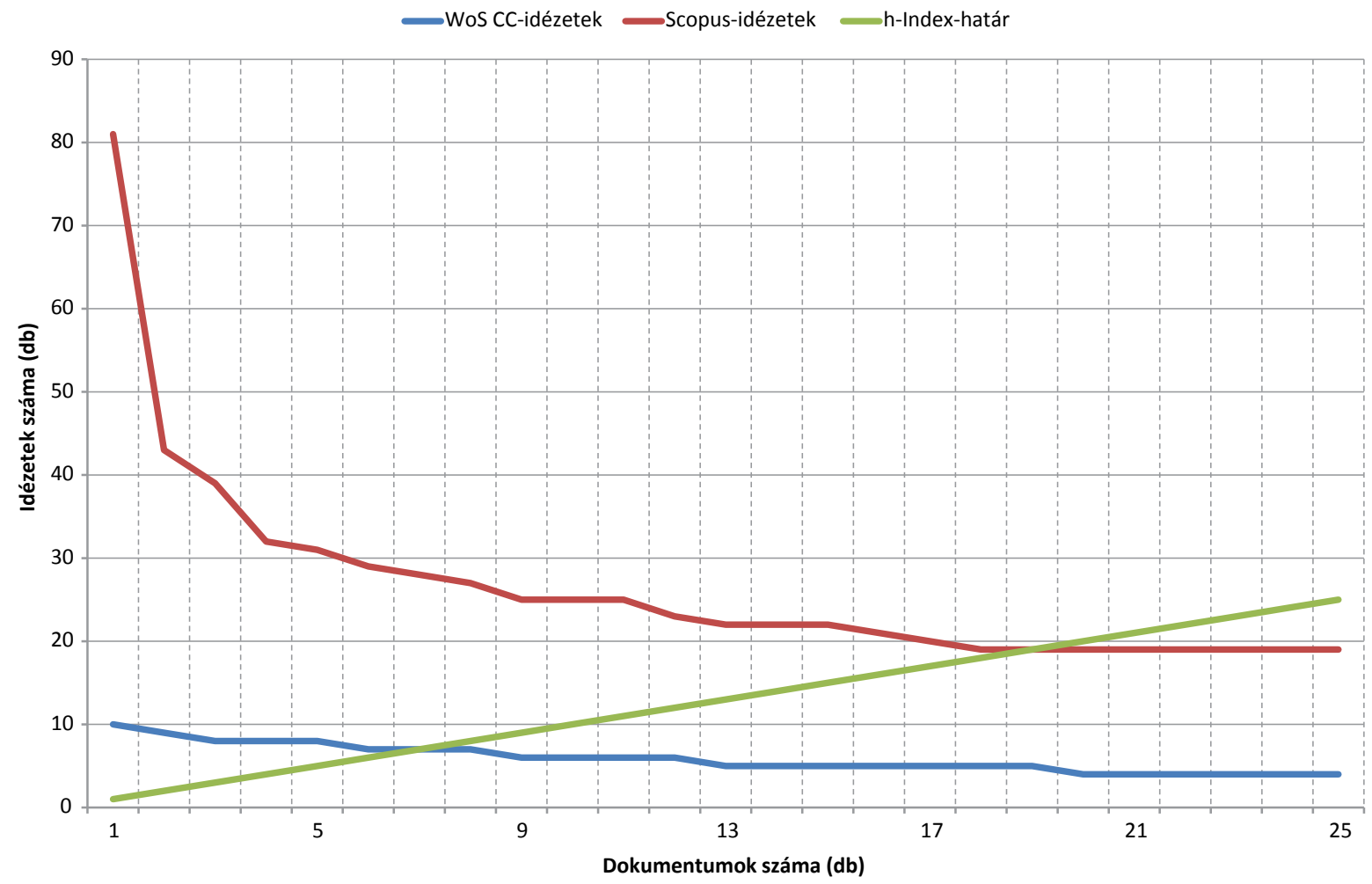

\begin{tabular}{l|l} 
9. ábra & A h-index a Web of Science Core Collection és a Scopus adatbázisban (a lekeresés ideje: 2017. december) \\
A rövidítés feloldását lásd a jelen közlemény rövidítésjegyzékében
\end{tabular} 
vizsgálja a h-index előnyeit, illetve hátrányait. A 9. ábra két világszerte elterjedt nemzetközi adatbázisban (WoS CC [5], Scopus [4]) lekeresett adatok alapján mutatja az Orvosi Hetilap h-index-értékét - fontos hangsúlyozni, hogy évek szúkítése nélkül. A h-indexet a kék-zöld, illetve a piros-zöld vonalak találkozási pontja adja: az Orvosi Hetilap h-indexe a WoS alapján 7, a Scopus alapján 19.

\section{Megbeszélés}

A táblázatok és ábrák első szemlélésekor a számadatok emelkedése tünik szembe a 2012-es adatokhoz képest: egyes esetekben duplázódtak az értékek, más esetekben enyhe növekedés figyelhető meg.

Az 1. táblázatban szereplő nem hivatalos és hivatalos IF-ok emelkedése számottevő a korábbi adatokhoz [1] viszonyítva. Ez egyértelmúen a hivatkozási számok növekedésének tudható be. Az utóbbi évek IF-értékeit öszszevetve az IF 0,3 körül mozgott, kivéve az IF 2016-ot, ahol megközelíti a 0,35-ös értéket. Felvetődhet a kérdés, hogy miért tettük be a 2012-2014-es nem hivatalos IFértékeket cikkünkbe. Szemléltetni szerettük volna, hogy nem látható éles váltás a 2014 előtti, illetve utáni IF-okban, holott 2014-től már a folyóirat önidézetei is bekerülnek a számlálóba. Ez jó hír, hiszen arra utal, hogy a folyóirat önidézetei még alacsonynak tekinthető tartományban találhatók; ugyan nincs meghatározva pontosan az önidézettségi határérték, de ismert, hogy a Clarivate Analytics komolyan vizsgálja a lehetséges visszaéléseket, ahogy a bevezetőben is említettük [1, 2]. A 2016-os IF idézetszámának emelkedésével kapcsolatban érdekes adatot kaptunk: az eddigi legtöbb idézetszámot hozó számlálóban a legmagasabb az önidézetek száma, de ha százalékosan összevetjük a 2016-ban az előző két évben megjelent Orvosi Hetilap-cikkekre érkezett idézetek számát, „csak” 31\%-ot kapunk, ami az eddigi átlagnak tekinthető - a 2012-es cikk a Scopus adatbázis adataira támaszkodva hasonló százalékos eredményt hozott [1]. Ez azt feltételezi, hogy nemcsak az önidézetek száma növekedett, hanem a nem Orvosi Hetilapból érkező idézetek száma is.

Ha már az idéző folyóiratokról esik szó, nézzük meg az Orvosi Hetilapot idéző, 3-nál magasabb IF-os folyóiratokkal összefüggő adatokat közelebbről. A több idézetszám nem feltétlenül generál magas IF-ú lapból érkező hivatkozást. Természetesen az eredeti és az összefoglaló cikkekre hivatkoztak elsősorban - erre utal a 4. ábra is -, de egy-egy esetismertetés hozhat pluszidézettséget. 2012-ben több mint 30-as IF-os lap nem idézett Orvosi Hetilapban megjelent közleményt, de az adatok összehasonlításával elmondhatjuk, hogy nincs nagy változás [1]: egyrészt hasonló IF-értékkel bíró lapok idézik évek óta az Orvosi Hetilap cikkeit, másrészt az eredeti és öszszefoglaló közlemények a legidézettebb közleménytípusok - jelen cikkünknél harmadikként, de „lemaradóként” követve az esetismertetések szerepelnek.
Fontos megemlíteni, hogy a 2012-es cikk megjelenése óta az Orvosi Hetilap online platformja megváltozott (http://akademiai.com/loi/650), 2015-től az Atypon szolgáltatói rendszerre váltott a folyóirat kiadója, az Akadémiai Kiadó. Ennek is köszönhető, hogy a folyóiratok kategóriaelnevezése is változott, egyszerüsödött. Míg 2012-ben eltérő elnevezésekkel szerepelhettek azonos kategóriák, például összefoglaló közlemény, illetve öszszefoglaló referátum [1], addig ez az új platformon sokkal jobban lekövethető.

Külön vizsgáltuk az Orvosi Hetilap közleményeire érkezett idézetek eloszlását open access, független hivatkozások szempontjából. Az 1. ábra egyértelmű emelkedést mutat a 2012-es cikk adataihoz [1] képest. Legalább másfélszer magasabb értékeket kapunk az utóbbi években érkezett idézeteknél, amelyeknek felét az open access közlemények idézettsége teszi ki. A 2. és 3. ábra hangsúlyozza a független hivatkozások külföldi és magyar arányát. Ami szembetűnő, hogy a 2012-es közlemény vonatkozó grafikonjaihoz [1] képest a külföldi hivatkozások alig emelkedtek, viszont a magyar hivatkozások ugrásszerúen megnövekedtek, akár öt-hatszoros értékkel. A külföldi, magyar elnevezések itt a szerzőség összetételére utalnak, és mivel minden esetben független hivatkozásokról van szó - azaz nem Orvosi Hetilapból érkező idézetekről -, az IF-értékeknél fentebb említett „önidézet-” túltengésról sem beszélhetünk.

A 2. táblázat adatai, be kell, hogy valljuk, csak igen óvatosan vethetők össze a 2012-es közlemény adataival [1]. Ennek több oka van: a korábbi cikk csak a független, azaz a nem Orvosi Hetilapból érkező hivatkozásokat listázta, míg a jelen publikációban csak a táblázatban csillaggal megjelölt adattárakban láthatunk független idézetszámot, általában az összes idézetszámot vettük figyelembe; továbbá jelenleg több idézetkereső adatbázis állt rendelkezésre, mint pár éve. A csillaggal megjelölt WoS adatbázisok nem indexelik az Orvosi Hetilapot, ezért találhatunk bennük csak független idézeteket az

2. táblázat |A 2012 és 2016 között megjelent Orvosi Hetilap-cikkek idézettsége több különböző idézetkereső adatbázisban (2017. novemberi adatok)

\begin{tabular}{lccccc}
\hline Év & $\begin{array}{c}\text { WoS } \\
\text { CC }\end{array}$ & $\begin{array}{c}\text { WoS } \\
\text { CSCD }\end{array}$ & $\begin{array}{c}\text { WoS } \\
\text { RSCI* }\end{array}$ & $\begin{array}{c}\text { WoS } \\
\text { SCIELO* }\end{array}$ & Scopus \\
\hline 2016 & 85 & 6 & 0 & 1 & 101 \\
2015 & 202 & 14 & 0 & 4 & 212 \\
2014 & 222 & 23 & 5 & 6 & 264 \\
2013 & 268 & 31 & 2 & 6 & 310 \\
2012 & $446^{*}$ & 64 & 6 & 6 & 543 \\
\hline Összes & 1223 & 138 & 13 & 23 & 1430 \\
\hline
\end{tabular}

A rövidítések feloldását lásd a jelen közlemény rövidítésjegyzékében. A *-gal jelölt adatbázisok/számok csak a független - azaz a nem Orvosi Hetilapból érkező - hivatkozásokat mutatják. 
idézetkeresési funkcióval. Mivel az Orvosi Hetilap cikkeinek bibliográfiai adataira csak 2013 óta kereshetünk a WoS CC adatbázisban, ezért annak 2012-es hivatkozásai is függetlennek minősülnek. A regionális citációs adatbázisok (WoS CSCD, RSCI, SciELO) értelemszerüen kevesebb hivatkozást hoznak a két nagy idézetkereső adattárhoz (WoS CC, Scopus) képest. A kínai citációs adatbázis számadata az egyetlen, amelyet nyugodtan öszszevethetünk a korábbi évek eredményével, és változást alig látni $[1,8]$. Ha pedig megnézzük a WoS platformján található idézetek összegét, szinte egyezik a Scopus hivatkozási számaival. Fontos kitételek, hogy az idézetkereső adatbázisok eredményei között átfedés lehet - a jelen közlemény ezeket az átfedéseket nem vizsgálta; valamint a WoS CC [5] citációs indexei közül a Semmelweis Egyetemen jelenleg előfizetett forrásokban kerestünk, úgymint Science Citation Index Expanded, Social Sciences Citation Index, Arts \& Humanities Citation Index, Emerging Sources Citation Index, Conference Proceedings Citation Index - Science, Conference Proceedings Citation Index - Social Science \& Humanities.

Az Orvosi Hetilap idézettségéhez kapcsolódóan pozitív változás, hogy a 2012-es cikk megjelenése óta [1] az Orvosi Hetilap cikkeinek absztraktjai után teljes „bibliográfiai minta" található, amely segíti az idézők munkáját; valamint lehetőség van közleményenként bibliográfiakészítő programba való exportálásra, ami megkönnyíti az idézési folyamatot, hisz manapság ritkán készülnek cikkek ilyen programok nélkül.

A SCImago oldalon [3] található mutatók közül a nemzetközi együttmüködésről elmondható, hogy lassú növekedés figyelhető meg 2012 óta, egy kisebb megugrás történt 2015-ben. A nemzetközi együttmúködést érdemes tovább erősíteni a jövőben is. A 6 . ábra átlagos idézettségi adatai láthatóan a 0,30 és 0,35 közötti tartományban mozognak egy-egy kivétellel, tehát viszonylag egyenletes teljesítményt nyújt ezen a téren is az elemzett folyóirat. Mint ahogy fentebb írtuk, a kékkel jelölt vonal adatait vethetnénk össze - legalábbis a SCImago leírása szerint [3] - az IF-értékekkel. Az összehasonlítás annyiban sántít, hogy két különböző forrás (JCR, illetve Scopus) szolgál alapul a számoknak. Érdekes, hogy nem találni utalást arra a SCImago oldalán [3], hogy a nevezőben található dokumentumszámokat szintén szűkíti idézhető cikkekre, de számolásaink alapján úgy tünik, ez a helyzet. Ha csak 2015-öt és 2016-ot nézzük, a következőkre jutunk: a hivatalos IF 2015-ben 0,291 [6], 2016-ban 0,349 [7]; az előző két évben megjelent dokumentumok átlagos idézettségi adata a SCImago alapján [3] 2015-ben 0,299, 2016-ban 0,315. Az imént említett összehasonlítási probléma ellenére a számok közelítenek egymáshoz. Volt már szó az IF bibliometriai összetevőinél a független idézetekről. A SCImago oldalán [3] összevethető adott időszakokban a közlemények összes, illetve önidézettsége. A 7. ábra az Orvosi Hetilap esetében vizsgálta ezt. Jó úton jár a folyóirat, hiszen ez az ábra is bizonyítja, hogy a kritikus önidézettségi ráta nem növekszik. A vizsgált években a legrosszabb önidézettségi arány 36\% (2014), de 2016-ban „csak” 27\%, fentebb az IF kapcsán 31\%-ról írtunk.

Az eddigi mutatószámokon túl érdemes megvizsgálni a Scopus CiteScore-értékeit (8. ábra). Egy viszonylag friss mérőszámról beszélhetünk, amely az IF-tól abban tér el, hogy adott évet megelőző három év dokumentumainak az idézettségét számolja, és a nevezőben található dokumentumok számát nem szúkíti csak idézhető dokumentumokra [11]. A Scopus adatbázison kívül külön weboldalon (https://journalmetrics.scopus.com/) is kereshetünk többek között ezekre a mutatószámokra is. A CiteScore-mérőszám hasonló értékeket mutat a vizsgált évekre vonatkozóan [14-18], talán a 2013-as és 2014-es értékek közötti eltérés lehet szembetűnő. A hányados mögé nézve a 2013-as CiteScore hozta a legtöbb idézettséget, a 2014-es pedig a legkevesebbet azonos dokumentumszám mellett, tehát a relatíve nagy különbség ebből adódhat. A 0,16 körüli - $\pm 0,07$ eltérésű - SJRértékek a vizsgált időszakban az alacsonyabb tartományban elhelyezkedő számadatok. A SNIP- [19] mutatószámmal összehasonlíthatjuk a különböző tudományterületi folyóiratok teljesítményét, ugyanis ez a mérőszám kiegyenlíti a szakterületek közötti idézési eltéréseket. A SNIP kifejlesztője a Universiteit Leiden Centre for Science and Technology Studies intézete - bővebb információ a metrikáról a következő oldalon található: http://journalindicators.com/methodology. Az Orvosi Hetilap esetében a SNIP kissé ingadozó számokat mutat 2012 és 2016 között, hol 0,2 feletti, hol 0,2 alatti adatokkal, itt kevésbé beszélhetünk egyenletességről [19].

A 9. ábrán látható h-index-érték nagy különbséget mutat a két adatbázisban $[4,5]$. Mi ennek az oka? A hindexet két szám határozza meg alapvetően: a dokumentumok és az idézetek száma, ezért erősen befolyásolja az érték alakulását, hogy egy adatbázisban mennyi közlemény-, illetve idézetszám található. Az Orvosi Hetilap h-indexei eltérésének fó oka, hogy míg a WoS CC 2013tól indexeli a lapot, így csak onnan számíthat dokumentumszámot, addig a Scopus 1949-tól jegyzi a folyóiratot. Ezek után nem csoda, hogy ekkora a különbség. Természetesen ha egyenlő feltételeket biztosítva azonos évtartományra (2013-2016) finomítanánk a keresést, a h-index is szinte egyezne: a WoS CC esetén 7, a Scopus esetén 10 lenne a h-index. Itt is mutatkozik azért némi eltérés, amelyet az indexelt lapok köre okozhat: a Scopusban több magyar nyelvű folyóiratot találunk, és ezáltal azok hivatkozásait is. Amiért nem szúkítettünk a 9. ábrán, annak magyarázata a SCImago oldalán keresendő: ha az Orvosi Hetilapra rákeresünk az oldalon, a folyóirat mellett a 18-as h-index-érték jelenik meg [3]. A Scopus szolgáltatja az adatokat, s mivel a Scopus gyakrabban, naponta frissül, a h-index ott jelen pillanatban 19. A h-index azonban bármikor módosulhat, fóleg egy aktív folyóirat esetében. A WoS CC adatbázisban jelenleg hét dokumentumról mondható el, hogy legalább heten vagy annál többen idézték [5]. Amint a nyolcadik 
közlemény eléri a nyolc hivatkozási számot, máris nyolcra vált a h-index. A Scopus esetében hasonló a helyzet: jelenleg tizenkilenc közleményről mondható el, hogy tizenkilencen vagy annál többen idézték [4]. Amikor a huszadik publikáció megkapja a minimum húsz idézetet, a h-index is ugrik húszra. Mivel a SCImago oldala ritkábban frissül, ott a tizennyolcas h-index látható a következő frissítésig [3].

Mint a módszernél leírtuk, nem teljesen lefedett a 2012-es [1] és a jelenlegi cikk tárgya, de ez nem is volt célunk, hiszen két különböző állapotot vizsgáltak: a WoS és IF előtti, illetve a WoS és IF utáni állapotot. Az újbóli idézetelemzés megmutatta, hogy - a mutatószámok függvényében - a hivatkozások, a különféle hányadosok ugyan emelkedhetnek, de csak hosszú távon eredményezhetnek látványos változást, amihez az alapot az eddigi mérôszámok szinten tartása és elérése teremti meg. A továbblépést segíthetik olyan újítások is, mint az Orvosi Hetilap hivatkozási stílusának beillesztése az EndNote bibliográfiai stílusokat tartalmazó listájába (Output Styles: http://endnote.com/downloads/styles), amelyet külön kérólapon (http://endnote.com/downloads/output-style-request) lehet kérelmezni; az absztraktok bővítése ábrákkal, képekkel, ami figyelemfelkeltó hatással bírhat; az open access közlemények növelése, hogy még több szakemberhez eljussanak az Orvosi Hetilap cikkei.

Az Orvosi Hetilap tehát jó úton halad az újabb mérföldkő eléréséhez, de ami igazán egyedivé teszi a nemzetközi tudományos lapok világában, hogy az egyetlen, a XIX. század óta heti rendszerességgel, magyar nyelven megjelenő, impaktfaktoros, nemzetközi adatbázisok által jegyzett orvostudományi folyóirat. Az „alapkőhöz” - megjelenés heti rendszerességgel, magyar nyelven mindmáig hú maradt a Markusovszky Lajos által alapított Orvosi Hetilap, ami a mai angol nyelven folyó tudományos életben önmagában elismerésre méltó teljesítmény. Ehhez kapcsolódóan fontos megjegyezni, hogy az 1857 óta megjelenő Orvosi Hetilap teljes tartalma digitálisan hozzáférhető többek között az Akadémiai Kiadó oldalán (http://akademiai.com/loi/650).

Anyagi támogatás: A közlemény megírása, illetve a kapcsolódó kutatómunka anyagi támogatásban nem részesült.

Szerzői munkamegosztás: B. A.: Az adatok lekeresése, elemzése, a kézirat megírása. Sz. P., V. L.: Szakmai iránymutatás, a kézirat kritikus átolvasása. A cikk végleges változatát mindhárom szerző elolvasta és jóváhagyta.

Érdekeltségek: A szerzőknek nincsenek érdekeltségeik.

\section{Irodalom}

[1] Berhidi A, Margittai Z, Vasas L. Looking back and moving forward: a bibliographic survey of the Hungarian-language Orvosi Hetilap. [Az Orvosi Hetilap bibliográfiai elemzése: visszatekintés és az előrelépés lehetőségei.] Orv Hetil. 2012; 153: 1905-1917. [Hungarian]

[2] Clarivate Analytics (2017). Title suppression from Journal Citation Reports. Available from: http://wokinfo.com/media/pdf/ jcr-suppression.pdf [accessed: December 20, 2017].

[3] SCImago (2007). SJR - SCImago Journal \& Country Rank. Available from: http://www.scimagojr.com [accessed: November 27, 2017].

[4] Elsevier (c2017). Scopus. Available from: https://www.scopus. com [accessed: December 19, 2017].

[5] Clarivate Analytics (2017). Web of Science Core Collection. Available from: https://webofknowledge.com/WOS [accessed November 11, 2017].

[6] Clarivate Analytics (2017). 2015 Journal Citation Reports. Available from: https://jcr.incites.thomsonreuters.com/ [accessed November 6, 2017].

[7] Clarivate Analytics (2017). 2016 Journal Citation Reports. Available from: https://jcr.incites.thomsonreuters.com/ [accessed November 7, 2017].

[8] Clarivate Analytics (2017). Chinese Science Citation Database. Available from: https://webofknowledge.com/CSCD [accessed November 11, 2017].

[9] Clarivate Analytics (2017). Russian Science Citation Database. Available from: https://webofknowledge.com/RSCI [accessed November 24, 2017].

[10] Clarivate Analytics (2017). SciELO. Available from: https://webofknowledge.com/sciELO [accessed November 24, 2017].

[11] Elsevier (c2017). Sources - Scopus. Available from: https:// www.scopus.com/sources [accessed: December 19, 2017].

[12] Berhidi A, Szluka P, Vasas L. New bibliometric indicators. Is this the end of the impact factor era? [Tudománymetriai újdonságok. Vége az impakt faktor egyeduralmának?] Magy Onkol. 2009; 53 : 115-125. [Hungarian]

[13] Braun T, Glänzel W, Schubert A. A Hirsch-type index for journals. Scientometrics 2006; 69: 169-173.

[14] Elsevier (c2017). CiteScore ${ }^{\mathrm{TM}} 2012$ for Orvosi Hetilap. Calculated by Scopus on 31 May 2013. Available from: https://www. scopus.com/sourceid/16438 [accessed: December 19, 2017].

[15] Elsevier (c2017). CiteScore ${ }^{\mathrm{TM}} 2013$ for Orvosi Hetilap. Calculated by Scopus on 31 May 2014. Available from: https:// www. scopus.com/sourceid/16438 [accessed: December 19, 2017].

[16] Elsevier (c2017). CiteScore ${ }^{\mathrm{TM}} 2014$ for Orvosi Hetilap. Calculated by Scopus on 31 May 2015. Available from: https:// www. scopus.com/sourceid/16438 [accessed: December 19, 2017].

[17] Elsevier (c2017). CiteScore ${ }^{\mathrm{TM}} 2015$ for Orvosi Hetilap. Calculated by Scopus on 31 May 2016. Available from: https:// www. scopus.com/sourceid/16438 [accessed: December 19, 2017].

[18] Elsevier (c2017). CiteScore ${ }^{\mathrm{TM}} 2016$ for Orvosi Hetilap. Calculated by Scopus on 31 May 2017. Available from: https:// www. scopus.com/sourceid/16438 [accessed: December 19, 2017].

[19] Universiteit Leiden CWTS (c2017). SNIP - Journal Indicator. Available from: http://journalindicators.com/Content/ CWTS\%20Journal\%20Indicators\%20June\%202017.xlsx [accessed: December 20, 2017].

(Berhidi Anna, Budapest, Üllői út 26., 1085 e-mail: berhidi.anna@semmelweis-univ.hu)

A cikk a Creative Commons Attribution-NonCommercial 4.0 International License (https://creativecommons.org/licenses/by-nc/4.0) feltételei szerint publikált Open Access közlemény, melynek szellemében a cikk nem kereskedelmi célból bármilyen médiumban szabadon felhasználható, megosztható és újraközölhető, feltéve, hogy az eredeti szerző és a közlés helye, illetve a CC License linkje és az esetlegesen végrehajtott módosítások feltüntetésre kerülnek. 